\title{
Analysis of $\mathrm{HCl}$ and $\mathrm{ClO}$ time series in the upper stratosphere using satellite data sets
}

\author{
A. Jones ${ }^{1}$, J. Urban ${ }^{2}$, D. P. Murtagh ${ }^{2}$, C. Sanchez ${ }^{2}$, K. A. Walker ${ }^{1}$, N. J. Livesey ${ }^{3}$, L. Froidevaux ${ }^{3}$, and M. L. Santee ${ }^{3}$ \\ ${ }^{1}$ Department of Physics, University of Toronto, Toronto, ON, Canada \\ ${ }^{2}$ Department of Earth and Space Science, Chalmers University of Technology, Gothenburg, Sweden \\ ${ }^{3}$ Jet Propulsion Laboratory, California Institute of Technology, Pasadena, CA, USA
}

Received: 5 February 2010 - Published in Atmos. Chem. Phys. Discuss.: 6 April 2010

Revised: 28 April 2011 - Accepted: 18 May 2011 - Published: 9 June 2011

\begin{abstract}
Previous analyses of satellite and ground-based measurements of hydrogen chloride $(\mathrm{HCl})$ and chlorine monoxide $(\mathrm{ClO})$ have suggested that total inorganic chlorine in the upper stratosphere is on the decline. We create $\mathrm{HCl}$ and $\mathrm{ClO}$ time series using satellite data sets extended to November 2008, so that an update can be made on the long term evolution of these two species. We use the HALogen Occultation Experiment (HALOE) and the Atmospheric Chemistry Experiment Fourier Transform Spectrometer (ACEFTS) data for the $\mathrm{HCl}$ analysis, and the Odin Sub-Millimetre Radiometer (SMR) and the Aura Microwave Limb Sounder (Aura-MLS) measurements for the study of ClO. Altitudes between 35 and $45 \mathrm{~km}$ and two mid-latitude bands: $30^{\circ} \mathrm{S}-$ $50^{\circ} \mathrm{S}$ and $30^{\circ} \mathrm{N}-50^{\circ} \mathrm{N}$, for $\mathrm{HCl}$, and $20^{\circ} \mathrm{S}-20^{\circ} \mathrm{N}$ for $\mathrm{ClO}$ and $\mathrm{HCl}$ are studied. ACE-FTS and HALOE $\mathrm{HCl}$ anomaly time series (with QBO and seasonal contributions removed) are combined to produce all instrument average time series, which show $\mathrm{HCl}$ to be reducing from peak 1997 values at a linear estimated rate of $-5.1 \% \mathrm{decade}^{-1}$ in the Northern Hemisphere and $-5.2 \%$ decade $^{-1}$ in the Southern Hemisphere, while the tropics show a linear trend of $-5.8 \%$ per decade (although we do not remove the QBO contribution there due to sparse data). Trend values are significantly different from a zero trend at the 2 sigma level. $\mathrm{ClO}$ is decreasing in the tropics by $-7.1 \% \pm 7.8 \% \mathrm{decade}^{-1}$ based on measurements made from December 2001 to November 2008. The statistically significant downward trend found in $\mathrm{HCl}$ after 1997 and the apparent downward $\mathrm{ClO}$ trend since 2001 (although not statistically significant) confirm how effective the 1987 Montreal protocol objectives and its amendments have been in reducing the total amount of inorganic chlorine.
\end{abstract}

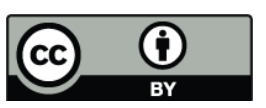

Correspondence to: A. Jones (ajones@atmosp.physics.utoronto.ca)

\section{Introduction}

Stratospheric ozone depletion is the result of anthropogenic release of chlorofluorocarbons (CFCs) in the troposphere. The lifetimes of the CFCs in the troposphere are very long allowing for a build up of concentrations of these gases, which are slowly transported to the stratosphere. CFCs are eventually photolysed in the stratosphere due to intense ultra violet radiation, where active chlorine $(\mathrm{Cl})$ is released and is available for the destruction of ozone (Molina and Rowland, 1974). However, due to the 1987 Montreal protocol agreement (and the subsequent adjustments), ozone depleting substance (ODS) emissions have slowly been phased out. It has been estimated that the total inorganic loading of tropospheric Cl peaked in 1993 (Rinsland et al., 2003) and has decreased by $\sim 5 \%$ through early 2002 (O' Doherty et al., 2004). As it is estimated that it takes 3-6 years for air to be transported into the middle and upper stratosphere (Stiller et al., 2008), then peak stratospheric values are suggested to be somewhere between 1996 and 1999 (WMO, 2006). Based on assumptions that the international agreements are adhered to, it is proposed using the equivalent effective stratospheric chlorine (EESC) parameter that total $\mathrm{Cl}$ values will reach pre 1980 levels around 2040 (Newman et al., 2007).

Two gases that are important contributors to the $\mathrm{Cl}_{\mathrm{y}}$ family $\left(\mathrm{Cl}_{\mathrm{y}}=\mathrm{Cl}+\mathrm{ClO}+\mathrm{HCl}+\mathrm{ClONO}_{2}+2 \mathrm{Cl}_{2} \mathrm{O}_{2}+\mathrm{HOCl}+\mathrm{OClO}\right.$ $+\mathrm{BrCl}+2 \mathrm{Cl}_{2}$ ) are hydrogen chloride $(\mathrm{HCl})$ and chlorine monoxide $(\mathrm{ClO}) . \mathrm{HCl}$ is important to the gas phase chemistry of ozone depletion because of its role as a reservoir species for $\mathrm{Cl}$. $\mathrm{ClO}$ on the other hand, carries most of the reactive chlorine in the stratosphere during day time. Past studies of these gases have suggested that there has been a slow down and even a decrease in the accumulation of $\mathrm{ClO}$ in the stratosphere using ground based measurements and satellite data sets (Considine et al., 1997, 1999; Anderson et al., 2000; Newchurch et al., 2003; Froidevaux et al., 2006; Solomon et al., 2006).

Published by Copernicus Publications on behalf of the European Geosciences Union. 
This study intends to examine the long term evolution of $\mathrm{HCl}$ and $\mathrm{ClO}$ using satellite data sets of the Halogen Occultation Experiment (HALOE), the Atmospheric Chemistry Experiment Fourier Transform Spectrometer (ACE-FTS), the Aura Microwave Limb Sounder (Aura-MLS), and the Odin Sub-Millimetre Radiometer (SMR). We examine altitudes from 35 to $45 \mathrm{~km}$ and mid-latitudes from $30^{\circ} \mathrm{S}-50^{\circ} \mathrm{S}$ and $30^{\circ} \mathrm{N}-50^{\circ} \mathrm{N}$ for $\mathrm{HCl}$ and $20^{\circ} \mathrm{N}-20^{\circ} \mathrm{S}$ for $\mathrm{ClO}$ and $\mathrm{HCl}$. The choice for investigating this altitude region is because $\mathrm{ClO}$ and $\mathrm{HCl}$ together make up more than $95 \%$ of the chlorine budget here (WMO, 2006). Additionally, it is in this altitude range where ozone is expected to show signs of a recovery first (Jucks et al., 1996). The analysis will make trend estimates based on monthly residual averaged data. By showing the current state of total inorganic chlorine in the stratosphere, we can ascertain if the Montreal protocol objectives are still working.

\section{$2 \mathrm{HCl}$ and $\mathrm{ClO}$ data sets}

\subsection{HALOE}

The HALOE instrument aboard the Upper Atmosphere Research Satellite (UARS) was operational from September 1991 to November 2005. HALOE employed a solar occultation instrument measuring many trace gases including $\mathrm{HCl}$. Observations were made in the infrared part of the electromagnetic spectrum (between 2.45 and $10 \mu \mathrm{m}$ ) (Russell et al., 1993). The HALOE occultation instrument was highly sensitive and obtained 15 occultation measurements during each sunrise/sunset by comparing the solar spectra to the spectra obtained whilst scanning through the atmosphere. This produced in essence a self calibrating instrument with long term stability. A vertical profile resolution of approximately $2-4 \mathrm{~km}$ was typically obtained for $\mathrm{HCl}$, between 10 and $65 \mathrm{~km}$. Global coverage from about $80^{\circ} \mathrm{N}$ and $80^{\circ} \mathrm{S}$ was achieved in approximately six weeks. As solar occultation relies on the sun, it means there will be no measurements made during polar night in the winter hemisphere. Moreover, it should be noted that the coverage of HALOE degraded over time and there were fewer measurements during the later years of the mission. We suggest the reader to consult (http://haloe.gats-inc.com/home/index.php) for more details. For the trend analysis, we ignore data for 1991 and 1992 to stay consistent with the work done by Newchurch et al. (2003). The reason for their analysis not to include these two years was due to the fact that the slope of a linear fit will be greatly affected by the beginning and ending data values. Because the HALOE data start during the Pinatubo period, they were very cautious to obtain a robust regression. Hence, they omitted any suspicious data. Data used in this analysis are from the HALOE v19 and can be obtained from http://haloe.gats-inc.com/home/index.php. The combined systematic and random uncertainties in the upper stratosphere are typically between 12 and $15 \%$, while correlative measurements with other instrument data show agreement between 8 and 19\% (Russell et al., 1996).

\subsection{ACE-FTS}

Another infrared solar occultation instrument yielding vertical profiles of $\mathrm{HCl}$ concentrations is the ACE Fourier Transform Spectrometer (ACE-FTS) (Bernath et al., 2005). The SCISAT platform maintains a low Earth repeating orbit with a geographical coverage between approximately $85^{\circ} \mathrm{S}-$ $85^{\circ} \mathrm{N}$, providing the opportunity for ACE-FTS to make typically 15 sunrise and 15 sunset solar occultations per day. Unlike HALOE, the ACE-FTS orbit does not change on a year to year basis, meaning that typically the same latitudes are sampled for a given time period.

Vertical profiles are retrieved from observed solar spectra using a non-linear least-squares global fit technique (Boone et al., 2005). Currently, $\mathrm{HCl}$ v2.2 VMRs are from $\sim 10$ $50 \mathrm{~km}$ with a vertical resolution of approximately $3-4 \mathrm{~km}$. Comparisons of ACE-FTS $\mathrm{HCl}$ to various other satellite and ground based instrumentation show that there is a good agreement of generally better than $5-10 \%$ above $20 \mathrm{~km}$ (Mahieu et al., 2008). At present, no error analysis for ACEFTS atmospheric products has been made. For this study, ACE-FTS v2.2 data are filtered according to various criteria: that the associated measurement uncertainty is not greater than $100 \%$ of the corresponding VMR value. Data used in this analysis are the ACE-FTS measurements from February 2004-November 2008.

\subsection{MLS}

Stratospheric $\mathrm{ClO}$ is studied using measurements of the Microwave Limb Sounder (Aura-MLS), which was launched in July 2004 on the NASA Aura satellite (from here on, we refer to Aura-MLS as MLS). This is the second MLS instrument, whereas the previous instrument, on board the UARS platform (hence, UARS MLS), operated for $\sim 8$ years between 1991 and 1999, but is not included in this analysis. MLS is a limb scanning instrument, observing thermal emission at millimetre and sub-millimetre wavelengths (Waters et al., 2006). MLS has the ability to measure at night and is not affected by stratospheric clouds. The Aura satellite maintains a suborbital track, covering $82^{\circ} \mathrm{S}$ to $82^{\circ} \mathrm{N}$ with an ascending node of 13:45 h local solar time (LST) and makes approximately 3500 scans per day.

MLS v2.2 $\mathrm{ClO}$ measurements are provided on pressure surfaces where the recommended levels to use are between 100 and $1 \mathrm{hPa}$. The vertical resolution and profile precision of the $\mathrm{ClO}$ measurements in this range are typically $3-$ $4.5 \mathrm{~km}$ and $\sim 0.1 \mathrm{ppbv}$ respectively. Comparisons to correlative measurements show the largest systematic uncertainties are found below $22 \mathrm{hPa}$ for both night time and day time measurements when compared directly to co-located ground and 
satellite measurements (Santee et al., 2008). However, this is of little relevance here as we examine MLS ClO measurements between 6.5 and $1.6 \mathrm{hPa}(\sim 35-45 \mathrm{~km})$ where systematic uncertainties are small.

MLS ClO data are screened using only profiles that have a zero status flag so that profiles with possible ambiguities are removed. Data are also only used if the quality flag is greater than 0.8. Moreover, we reject values that have a poor convergence criterion such that it is larger than 1.5. Finally, values that possess a negatively flagged uncertainty (precision) are also rejected. Please see Santee et al. (2008) for more details.

\section{$2.4 \operatorname{Odin} / \mathrm{SMR}$}

The Odin satellite was launched in the beginning of 2001 and is a joint initiative between Sweden, Canada, Finland and France. This small satellite comprises two instruments, the Sub-Millimetre Radiometer (SMR) and the Optical Spectrograph InfraRed Imager System (OSIRIS). The Odin satellite is polar orbiting $\left(82.5^{\circ} \mathrm{S}\right.$ to $\left.82.5^{\circ} \mathrm{N}\right)$ and is sun synchronous with a descending node at $06: 00 \mathrm{~h}$ and ascending node at 18:00 h LST. The SMR instrument makes measurements of various species including stratospheric $\mathrm{ClO}$ by observing thermal emission in the microwave region during day and night (Murtagh et al., 2002; Frisk et al., 2003). SMR consists of five receivers, where we use $\mathrm{ClO}$ from the $501.8 \mathrm{GHz}$ band. We remove profiles if the quality flag is not equal to zero or for any observation with a measurement response less than 0.75 .

The newest version of SMR, data version 2.1 (produced at the Chalmers University of Technology, Sweden), is used for the analysis of stratospheric ClO. The study by Santee et al. (2008) compares coincident MLS and SMR measurements, and it is found that there is an excellent agreement for altitudes between 35 and $45 \mathrm{~km}$ (within $0.1 \mathrm{ppbv}$ ). An overview of the SMR ClO measurements can be found in Urban et al. $(2005,2006)$. Note that SMR v2.1 and v2.0 ClO products are virtually identical. The vertical resolution for the $\mathrm{ClO}$ product at $501.8 \mathrm{GHz}$ is $2-4 \mathrm{~km}$ in the stratosphere.

\section{Methodology}

Here, we describe the methods used in order to derive long term trends of stratospheric $\mathrm{HCl}$ and $\mathrm{ClO}$. We use separate methodologies for each species, although a linear regression analysis is used in each case to derive the resulting trends.

\subsection{HCl}

As the main focus of the $\mathrm{HCl}$ analysis is on the upper stratosphere, we firstly filter both HALOE and ACE-FTS data between 35 and $45 \mathrm{~km}$ into three latitude bands: $30^{\circ} \mathrm{S}-50^{\circ} \mathrm{S}$, $20^{\circ} \mathrm{S}-20^{\circ} \mathrm{N}$, and $30^{\circ} \mathrm{N}-50^{\circ} \mathrm{N}$. Monthly averages are calculated for the filtered data. Each data set comprises a large number of measurements, implying that the stochastic error should be minimised when measurements are averaged. We have chosen these altitude ranges firstly because the first signs of ozone recovery are expected to be seen in the upper stratosphere (Jucks et al., 1996) and since this upper altitude range is also studied by other analyses and hence the results found here can easily be compared (for example, Newchurch et al. (2003). Figure 1 illustrates the monthly averaged time series for each data set for the three latitude bands mentioned above. Due to the SCISAT orbital parameters and due to the nature of the viewing geometry, ACEFTS measurements are sparse in the tropics, and eventual trend estimates in the tropics have to be treated with more care compared to the mid-latitude cases. In all three cases there is an apparent $\sim 0.2-0.4 \mathrm{ppb}$ positive ACE-FTS bias compared to the HALOE observations during overlapping measurement periods. This technique does not follow the conventional comparison method of profile to profile comparisons, but rather compares time series of average measurements over a long period of time as they are used in this analysis. Mismatches are thus possible in terms of time and space. This result agrees with similar analyses made by Mahieu et al. (2008), who show that there is 10-20\% ACEFTS bias compared to HALOE for altitudes between 20 and $55 \mathrm{~km}$. Work by Froidevaux et al. (2008) also show that the biases between MLS and HALOE are of a similar magnitude in the same altitude region. Moreover, MLS and ACE-FTS $\mathrm{HCl}$ data agree better than either versus HALOE. Additionally, it has also been shown that HALOE is biased low versus other correlative data, based on the Russell et al. (1996) $\mathrm{HALOE} \mathrm{HCl}$ validation paper. Interesting features are the peak in HALOE values until around 1997 after which values start to slowly decrease until instrument termination at the end of 2005. However, there is a large degree of variability in the values between 1997 and 2002, which is also seen in previous findings for HALOE $\mathrm{HCl}$ observations at $55 \mathrm{~km}$ (Waugh et al., 2001; WMO, 2006), although these features are not fully understood. The ACE-FTS time series exhibits strong seasonal variations, especially in the Southern Hemisphere (lower panel) and tropics (middle panel). The tropics also exhibit smaller interannual variations due to the semi-annual oscillation (SAO), typically present at these altitudes, although data here are limited as occultation geometry does not continuously cover tropical latitudes. The seasonal and inter seasonal variations are less apparent in the Northern Hemisphere (top panel) compared to the Southern Hemisphere. This difference could be a consequence of stronger wave activity in the Northern Hemisphere in comparison to the Southern Hemisphere. If this is the case, then the end result is that the seasonal variations in the Northern Hemisphere will be masked due to the increased turbulent mixing in the surf zone of the northern mid-latitudes. HALOE values exhibit more noise in the measurements as they have a lower sampling rate compared to ACE-FTS (HALOE typically $50-350$ profiles globally a month, ACE-FTS typically 

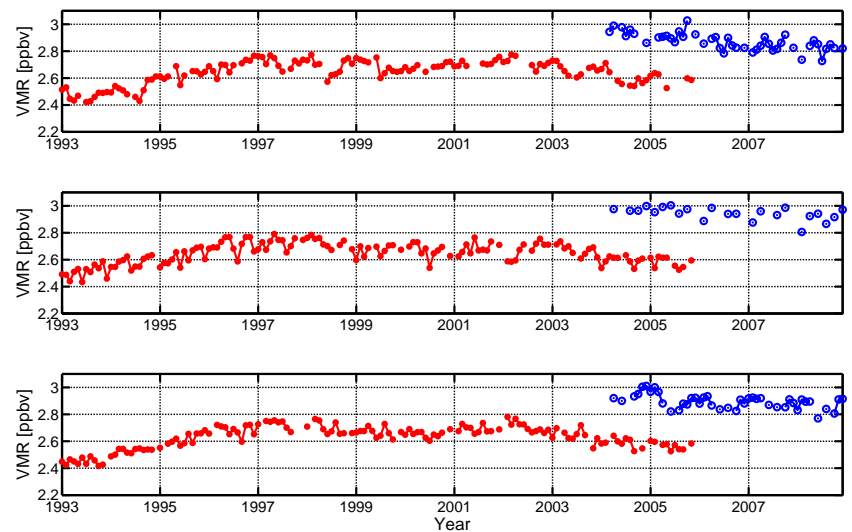

Fig. 1. Monthly averaged $\mathrm{HCl}$ measurements for HALOE (red) and ACE-FTS (blue) for $35-45 \mathrm{~km}$ in three latitude bands. Top, $30^{\circ} \mathrm{N}-$ $50^{\circ} \mathrm{N}$. Middle, $20^{\circ} \mathrm{S}-20^{\circ} \mathrm{N}$. Bottom, $30^{\circ} \mathrm{S}-50^{\circ} \mathrm{S}$.

$>300-500$ profiles a month). A typical example of spatial coverage for all four instruments studied in this analysis is illustrated in Fig. 2. Here, the HALOE and ACE-FTS orbital paths represent the typical spatial coverage completed during one month, while the SMR and MLS orbital paths are the typical spatial coverage for observations made during one day.

\subsubsection{Removing known sources of variation}

The variations of each individual time series are cyclic in nature and are associated mainly to seasonal cycles (including SAO) and the quasi-biennial oscillation (QBO). HCl's response to variations in solar intensity are small between 35 and $45 \mathrm{~km}$ (Egorova et al., 2005) and is not accounted for in this analysis. By being able to separate the relative contributions of known variation (by the process of linear regression), we will be left with the unexplained variability of the monthly mean signal to which a linear trend can be applied. We follow similar approaches to that of Newchurch et al. (2003), and Steinbrecht et al. (2004, 2006), where we firstly remove the seasonal cycle from the $\mathrm{HCl}$ time series. This is simply done for each instrument by finding the difference between each monthly mean value from their corresponding average (climatological) annual cycle. For example, the HALOE mean January value calculated for all Januarys during 1993-2005 is subtracted from each individual HALOE January VMR value. Hence, the resulting HALOE and ACE-FTS time series will be a monthly mean $\mathrm{HCl}$ time series with the seasonal components removed, but still containing contributions from the QBO and other sources of variation.

In order to model the $\mathrm{HCl}$ anomalies from HALOE and ACE-FTS time series (with the seasonal component already removed), we apply a linear regression model to each set of anomalies independently, accounting for fluctuations related to the QBO

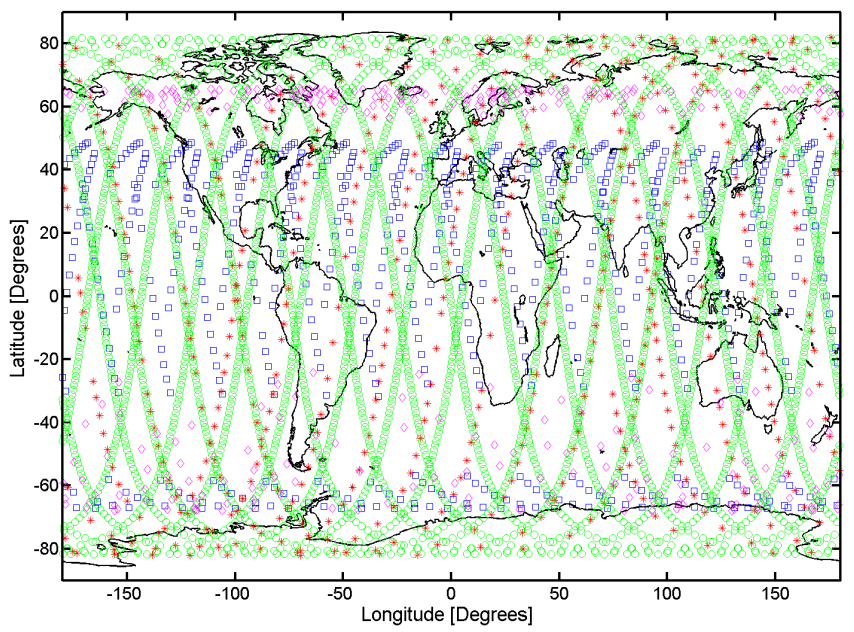

Fig. 2. Spatial coverage of the satellite instruments used. Blue squares indicate HALOE, magenta diamonds indicate ACEFTS, red stars indicate Odin-SMR, and green circles indicate MLS. HALOE and ACE-FTS measurements are for the month of January 2005. MLS and SMR observations are for the 1 January 2005.

$\left[\Delta \mathrm{HCl}_{t}=b+a t+\sum_{i=1}^{\mathrm{QBO}}\left(c_{i} \cos \left(\frac{2 \pi t}{P_{\mathrm{QBO}}(i)}\right)+d_{i} \sin \left(\frac{2 \pi t}{P_{\mathrm{QBO}}(i)}\right)\right)+N_{t},(1)\right.$

where $\Delta \mathrm{HCl}(t)$ are the $\mathrm{HCl}$ anomalies calculated for each month, $t$. The first and second components in the model represent a linear trend, where $b$ is a constant when time $t=0$ and $a$ is a linear fit coefficient. The third set of terms represents the QBO cycle, which is a combination of cosine and sine wave functions, which use harmonics, $P_{\mathrm{QBO}}(i)$, that best represent the behaviour of the QBO cycle. The last term in the model, $N_{t}$, is the residual or autocorrelated error term, which is an autoregressive process such that, $N_{t}=\theta N_{t-1}+e_{t}$, where $\theta$ is the autocorrelation (lag 1 month) and $e_{t}$ are the white noise residuals with zero mean and common variance. As we have already removed the seasonal cycle prior to this step, there is no need to include a seasonal cycle component. We have chosen to do this as we treat the tropical bin slightly different since we do not fit for the QBO parameter. The reason for this is due to the sparse contribution of ACE-FTS $\mathrm{HCl}$ data between $20^{\circ} \mathrm{S}-20^{\circ} \mathrm{N}$, which causes difficulties in estimating reliable harmonics representing the cyclic behaviour of the QBO.

The linear fit, $a$, calculated for each independent set of anomalies is the estimated fit over each entire time series. However, $a$ is solely a product of our estimation of the cyclic behaviour of each full time series and is only used for calculating the QBO contribution. This makes sense since the HALOE time series, for example, does not maintain a linear trend for its entirety, as can be seen from Fig. 1. It should also be noted that subtraction of the monthly mean values (for deseasonalisation) will be reflected in the axis intercept $b$ (compared to a (possible) fit to the original $\mathrm{HCl}$ time-series). 
The terms $a, b, c$ and $d$ need to be calculated so that the total summed contribution of the QBO can be determined. Hence, Eq. (1) can be solved for pre-determined QBO cycles $\left(P_{\mathrm{QBO}}(i)\right)$ by least squares analysis such that the sum of the squares of the residuals is minimised. Thus, the remaining $\mathrm{HCl}$ monthly anomalies are from sources of variability that cannot be explained by seasonal or QBO behaviour. The fundamental period of the QBO in the tropics is around 30 months, but there are also smaller periods modulating around 12 months, especially relevant for the mid-latitudes (Baldwin et al., 2001). Furthermore, Steinbrecht at al. (2004) showed statistically significant (at $90 \%$ ) periods found in ground-based stratospheric ozone data, to be between 7.5 and 32.2 months. Here, we estimate the QBO signals by examining the $\mathrm{HCl}$ deseasonalised time series directly, when passed through a fast Fourier transform (FFT). Large peaks observed between 7-9, 16-22, and 26-32 months in the resulting FFT power spectrum give an estimate to those cycles that are due to the $\mathrm{QBO}$ and are used as $P_{\mathrm{QBO}}(i)$ in the regression model. We then compare the summed QBO component to zonal wind data provided at $10 \mathrm{hPa}$ over Singapore to ensure that the modeled QBO component has the correct degree of phasing, such that there will be a phase shift in the modeled QBO output due to the delay in the transport of air from the tropics (typically 6-18 months Stiller et al., 2008).

\subsubsection{Applying a trend to anomaly time series after seasonal and QBO components are removed}

Examination of the HALOE anomalies (with the season and QBO contributions removed) for the southern mid-latitude bin in Fig. 3, shows little difference in structure for the same bin to that exhibited in Fig. 1. The Northern Hemisphere mid-latitude and tropics bin show similar structures, (not shown here), hence we assume that the turnaround time for $\mathrm{HCl}$ to be 1997 for both bins, which also agrees with EESC peak times in this altitude range (Newman et al., 2007; WMO, 2006; Schoeberl et al., 2005). In order to quantify the HALOE anomalies, we would like to try and estimate a linear trend before and after 1997. This can be done by applying the change in linear trend method suggested by Reinsel et al. (2002). Here, a piece-wise linear trend is defined over the total time series period, $T$, such that there is a change in trend magnitude at a given time, $t=T_{0}$ and is described here as

$\left[\Delta_{\mathrm{HALOE}} \mathrm{HCl}\right]_{t}=b+a_{1} X_{1 t}+a_{2} X_{2 t}+N_{t}$,

where $\Delta_{\mathrm{HALOE}} \mathrm{HCl}(t)$ are the HALOE $\mathrm{HCl}$ anomalies to be modeled with seasonal and QBO parameters removed. $X_{t}$ is a linear trend function, $b$ is the intercept at $t=0$, while $a_{1}$ is the trend at time $t=0$, and $a_{2}$ signifies the magnitude of a possible change in trend at time $t=T_{0}$. Thus

$X_{1 t}=t$ where $0<t \leq T$

$X_{2 t}=\left\{\begin{array}{cc}0 & 0<t \leq T_{0} \\ \left(t-T_{0}\right) & T_{0}<t \leq T\end{array}\right\}$.

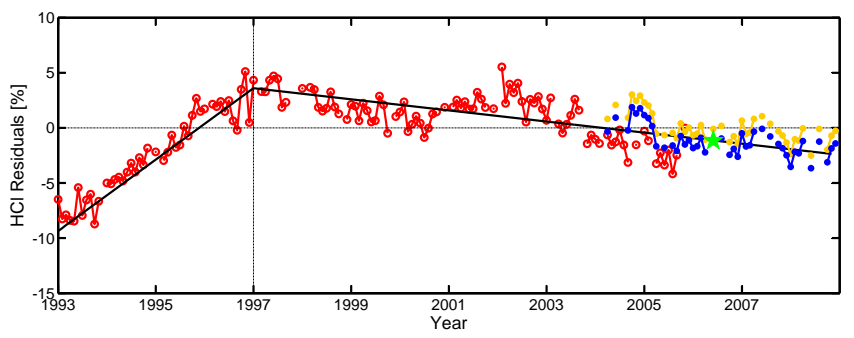

Fig. 3. HALOE (red line circle) and ACE-FTS anomalies (orange dot line) for $30^{\circ} \mathrm{S}-50^{\circ} \mathrm{S}, 35-45 \mathrm{~km}$ after seasonal and QBO terms are removed. ACE-FTS anomalies are shifted so that they align with the HALOE values (blue dot line). The solid black line indicates the fit line of HALOE extrapolated beyond 2005. The dashed line indicates the turn around year for HALOE HCl values (1997). The green star indicates the mean value along the HALOE fit line during the overlapping period with ACE-FTS. The value at the star is the offset value, which is applied to the ACE-FTS anomalies so that they shift relative to the HALOE anomalies for the overlapping time period.

Hence, Eq. (2) can be simplified to

$\left[\Delta_{\mathrm{HALOE}} \mathrm{HCl}\right]_{t}=b-a_{2} T_{0}+t\left(a_{1}+a_{2}\right)$

$a_{2}=0$ where $t<T_{0}$. From this linear regression model two different trends will be calculated: a trend $\left(a_{1}\right)$ before a turning point and one that implies a change in trend $\left(a_{2}\right)$ after the turning point, such that the new trend after the turning point, $a=a_{1}+a_{2}$. In order for this method to work, one assumes that there is a change in trend and that the transition is continuous. Hence, for the case in Fig. 3, it is possible to model linear fits to the HALOE anomalies such that there is a change in trend in January 1997 and this methodology is applied to each HALOE anomaly time series from each bin.

The change in trend method is not needed for the ACEFTS anomalies as the data set started in 2004 and the decline in $\mathrm{HCl}$ is approximately linear. However, we can use the ACE-FTS anomalies to extend the HALOE time series, which finishes in 2005. As the HALOE and ACE-FTS anomalies both fluctuate around zero, we need to apply an offset to the ACE-FTS anomalies so that they align with the HALOE anomalies. By using the post 1997 linear fit line calculated from the HALOE anomaly time series, we can apply such an offset to the ACE-FTS anomalies so that they fit relative to the HALOE anomalies. As HALOE terminated in November 2005, it means that there is only 15 months worth of data overlap between ACE-FTS and HALOE. We make an important assumption that the post 1997 HALOE fit line can be extrapolated to cover the whole period covered by ACEFTS (as shown in Fig. 3). As the ACE-FTS anomalies show no large changes in trend after HALOE's termination, there is good reason to believe that this assumption is valid. The offset is simply determined by calculating the mean value of the HALOE fit line during the overlapping time of the ACEFTS anomalies. For the case shown in Fig. 3 the ACE-FTS 
anomalies are offset by $-1.15 \%$ (as indicated by the green star in Fig. 3). It should be noted that due to the measurement noise and the natural variability of the atmosphere there will be a residual offset uncertainty, which contributes to the overall correlated error term in the trend uncertainty.

When the ACE-FTS anomaly time series is aligned correctly with the HALOE anomalies, we can then create an all instrument average where both instrument anomaly time series are combined and averaged. Hence, where there is data overlap between ACE-FTS and HALOE an average of the two is calculated. Due to the influence of the ACEFTS anomalies in the all instrument average, it means that the original estimated trends calculated only for the HALOE time series using Eq. (2) will now need updating. Hence, we make new trend calculations based on the all instrument average produced in each bin, $\Delta_{\mathrm{All} \text { _inst }} \mathrm{HCl}(t)$, before and after 1997 using Eq. (2).

\section{$3.2 \mathrm{ClO}$}

Similarly to the $\mathrm{HCl}$ analysis, we have decided to investigate $\mathrm{ClO}$ in the upper stratosphere, from 35 to $45 \mathrm{~km}$, but only for the tropics between $20^{\circ} \mathrm{S}$ to $20^{\circ} \mathrm{N}$. As MLS makes retrievals on pressure surfaces, we filter data by using approximate pressure surfaces that closely match the geometric altitude zones used here: $6.4-1.6 \mathrm{hPa} \sim 35-45 \mathrm{~km}$. As $\mathrm{ClO}$ has a strong diurnal variation, it is important to consider the local solar time (LST) of the measurements of both SMR and MLS. As SMR has an ascending node around 06:00 $\mathrm{h}$ and descending node around 18:00 h, we expect the satellite to pass between $20^{\circ} \mathrm{S}$ to $20^{\circ} \mathrm{N}$ somewhere between 05:00-07:00 $\mathrm{h}$ and 17:00-19:00 $\mathrm{h}$. A similar principle applies to MLS, which observes $\mathrm{ClO}$ in the ascending node from 12:45-14:45 $\mathrm{h}$ and descending node from $00: 45-02: 45 \mathrm{~h}$ for this latitude range. Hence, data must be also filtered according to time of day.

On examination of the SMR measurements, it was found that the ascending and descending node LSTs have been slowly drifting forwards since Odin's launch. The reason for this is because the Odin satellite has slowly descended from its initial position during its mission. Figures 4 and 5 illustrate the effect that this has on the monthly averaged $\mathrm{ClO}$ measurements for both dawn and dusk, illustrating the ascending and descending nodes respectively. As a result of increasing LST, it also means that the solar zenith angle (SZA) has slowly decreased over time during morning scans and increased during evening scans. The overall concentrations observed by SMR have therefore slowly increased (morning) or decreased (evening) over time. This causes problems if a trend analysis is to be made using the SMR data set as the induced trend in the measurements from the increased LST will be the dominating feature. For the record, we do not see such problems using MLS for either day or night time measurements since the Aura satellite has orbit stabilization.

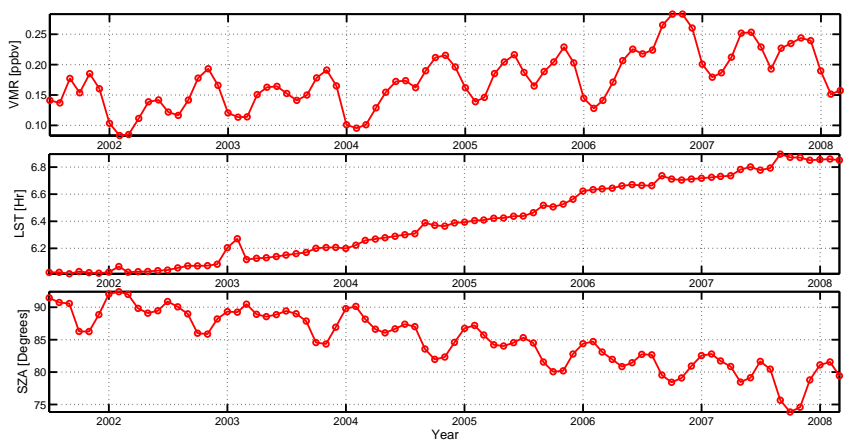

Fig. 4. Monthly averaged $\mathrm{SMR} \mathrm{ClO}$ concentrations as a function of time (for binned profiles, $20^{\circ} \mathrm{S}-20^{\circ} \mathrm{N}, 35-45 \mathrm{~km}$ ), taken for ascending node scans. Middle, SMR LST as a function of time. Lower, SMR SZA as a function of time.

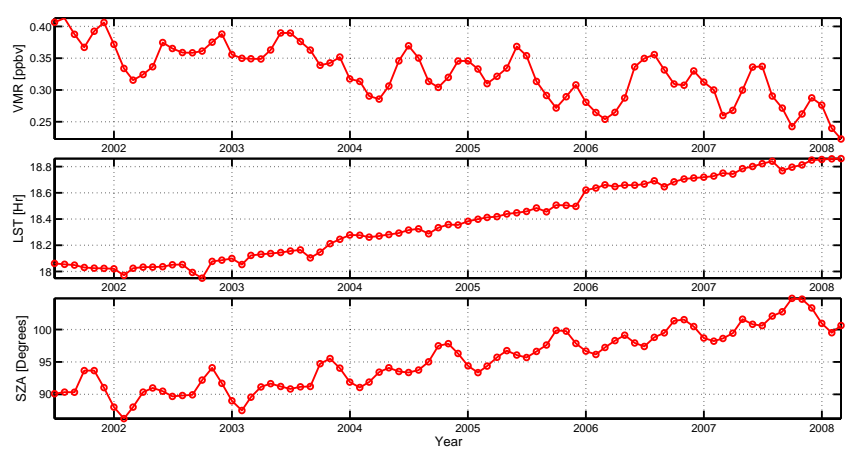

Fig. 5. Same as Fig. 4, except results are for descending node scans.

To deal with this problem, we utilise a 1-D atmospheric chemistry box-model that models the stratosphere between 25 and $55 \mathrm{~km}$ (Jonsson, 2006) and adapts a similar approach to that used in previous studies (Brohede et al., 2007a, b; Bracher et al., 2005). The model contains no dynamical features in the altitude/latitude region of interest and is solely controlled by chemical processes. The model is initialised by zonally averaged vertical profiles of $\mathrm{O}_{3}, \mathrm{H}_{2} \mathrm{O}, \mathrm{CH}_{4}, \mathrm{HCl}$, $\mathrm{NO}$, and $\mathrm{NO}_{2}$, measured by HALOE at times during either sunrise or sunset. Variations of these trace gases are then calculated during a $24 \mathrm{~h}$ period. Furthermore, other important trace gases (such as $\mathrm{ClO}$ ), are also determined from the chemical reactions that are used within the model. A full diurnal multiple scaling radiation scheme is used. The model can be run repeatedly, simulating the same physical conditions for a particular day (for example, the same sunlit conditions, pressure, temperature etc.), where the start of a new run is forced to be re-initialised by the same HALOE observations. As the species measured by HALOE give relatively good information regarding ozone and $\mathrm{Cl}_{\mathrm{y}}$ chemistry, it means that the procedure forces the model to be constrained by the HALOE observations during each new run's initialisation. By doing this, it means that any uncertainties in 
the modelling of the HALOE gases are reduced. Moreover, by modelling the same day consecutively 15 times or longer ensures that all the chemical abundances in the model converge, such that subsequent model runs produce insignificant changes for all modeled species.

In this study, we use the box model to simulate diurnal $\mathrm{ClO}$ values for $1 \mathrm{~km}$ altitude steps from $35-45 \mathrm{~km}$ at the equator and during the day of equinox (spring, autumn would produce the same results). Essentially, each $\mathrm{ClO}$ diurnal cycle can be expressed as a function of SZA, which in itself is a function of time. The purpose of doing this is to calculate scaling factors, allowing for the binned SMR profiles to be scaled to a specific SZA, $\theta$. This means for the equivalent satellite SZA, $\theta_{\text {obs }}$, the model values will yield a scale factor, $s f$, which is then applied to the satellite measurement,

$Y_{\text {scl }}\left(\theta_{\text {mod }}, z\right)=\underbrace{\frac{Y_{\text {mod }}\left(\theta_{\text {mod }}, z\right)}{Y_{\text {mod }}\left(\theta_{\text {obs }}, z\right)}}_{s f} Y_{\text {obs }}\left(\theta_{\text {obs }}, z\right)$

where $Y_{\mathrm{obs}}$ is the observed concentration profile, $Y_{\mathrm{mod}}$ represents the model values, $Y_{\text {scl }}$ is the scaled concentration profile, and $z$ is the vertical coordinate. For this study we chose $\theta_{\text {mod }}=90^{\circ}$ am (i.e. morning). In order to make a fair comparison, we also treat the MLS data in the same manner, such that both data sets contain profiles corrected for diurnal variation (according to Eq. 4) from 35 to $45 \mathrm{~km}$ that can be used to produce monthly means based solely for when $\theta_{\text {mod }}=90^{\circ} \mathrm{am}$. More importantly, it removes the LST problem concerning the SMR measurements and time of day no longer is an issue. A graphical illustration of the scaling process is given in Fig. 6.

When making a trend analysis the absolute values of the scaled monthly means are irrelevant as we only consider relative units by firstly removing the seasonal cycle (similar to that of the $\mathrm{HCl}$ method). A linear regression analysis is made (according to Eq. 1) on each set of scaled deseasonalised anomalies. We do not fit for the solar cycle since the time series length of each data set is too short. Mean $\mathrm{ClO}$ changes due to 11-year solar forcing are typically $0-2 \%$ between 35 and $45 \mathrm{~km}$ (Egorova et al., 2005). Thus the remaining scaled anomalies will have the QBO and seasonal cycles removed, but will still include the solar cycle contribution. We apply an offset to the MLS anomalies so that they fit relative to the SMR anomalies. An all instrument average is created by combining the overlapping MLS (after applied offset) and SMR anomalies. Finally, a linear trend line is fitted to the all instrument average.

For reference, we have also analysed measurement scale factors based on other times of the year, including the winter and summer solstices. It means that the observations are scaled differently owing to different conditions compared to those at equinox. Such conditions are related to parameters like solar intensity (as a result of the alternating distance from the Earth to the Sun during an annual cycle) and variations in

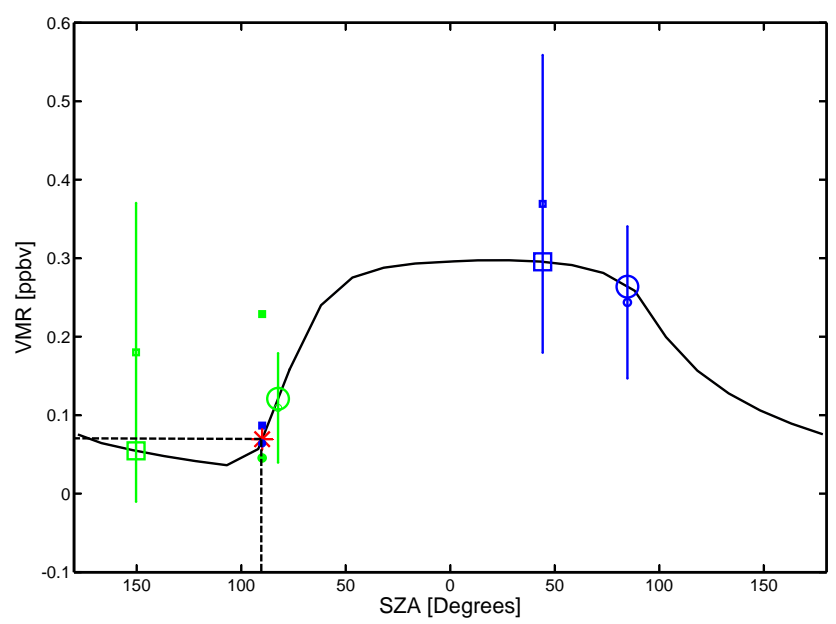

Fig. 6. An illustration of how the scale factors are calculated from Eq. (4) for measurements at $z=40 \mathrm{~km}$. ClO diurnal cycle (black line) as a function of time (SZA). Satellite observations $Y_{\mathrm{obs}}\left(\theta_{\mathrm{obs}}, z\right)$ are symbolized by either an open small circle (SMR) or an open small square (MLS). The observations are colour coded such that green $=\mathrm{AM}$ observations and blue $=\mathrm{PM}$ observations. The vertical solid lines are the corresponding measurement uncertainties. The large open circles correspond to $Y_{\bmod }\left(\theta_{\text {obs }}, z\right)$. The red asterisk is the $Y_{\text {mod }}\left(\theta_{\text {mod }}, z\right)$, where $\theta_{\text {mod }}=90^{\circ}$ am. The resulting scaled measurements $Y_{\text {scl }}\left(\theta_{\text {mod }}, z\right)$ are shown as small filled circles (SMR) or squares (MLS). Corresponding scaled measurement uncertainties are not shown.

the maximum SZA during an annual cycle. However, we do not find any significant differences in the overall trend magnitudes using simulated diurnal cycles from the winter and summer solstice cases, therefore the choice of using a $\mathrm{ClO}$ diurnal cycle for equinox is justified.

\section{Results}

\subsection{HCl}

Figure 7 shows the all instrument average for combined HALOE and ACE-FTS anomalies in the three bins analysed. Each bin shows an increase in $\mathrm{HCl}$ values monotonically until around 1997. Values slowly start to decrease after 1997 and by mid 2008 they are typically 5-6\% lower than the 1997 turn around anomaly estimates.

Concerning the mid-latitudes, we find that in each bin $\mathrm{HCl}$ values increase by $27 \%$ decade $^{-1}$ in the Northern Hemisphere and $32.4 \%$ decade $^{-1}$ in the Southern Hemisphere until 1997. In each case the trend magnitudes are statistically significant from a zero trend at $2 \sigma$ (or at $95 \%$ confidence level). Error estimates are calculated using an algorithm suggested by Weatherhead et al. (1998). The trends calculated here are larger than those found by Newchurch et al. (2003), who examined $\mathrm{HCl}$ for the same altitude region using HALOE data from 1993-2003. This could be a 

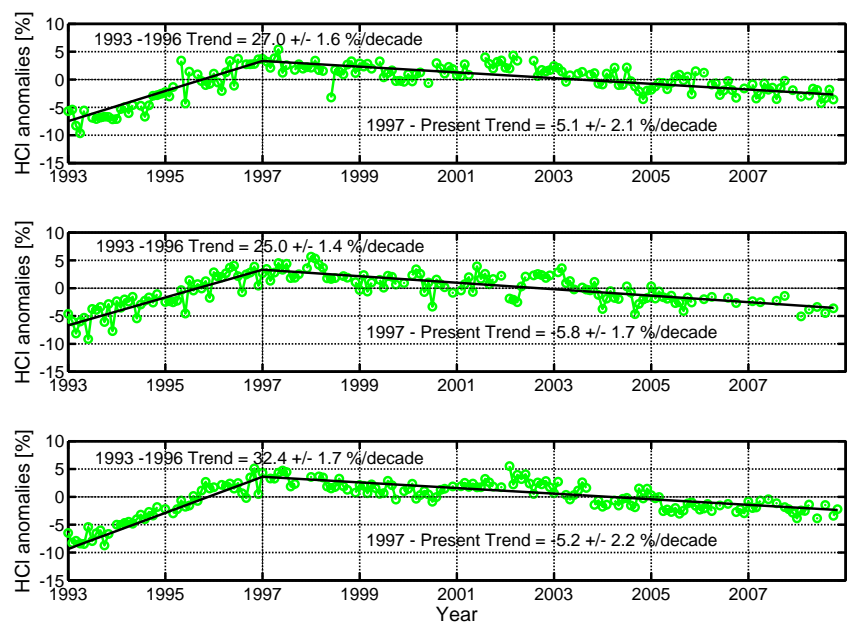

Fig. 7. $\mathrm{HCl}$ anomalies for the all instrument average (green) produced from HALOE and ACE-FTS monthly averaged data between 35 and $45 \mathrm{~km}$. Top $30^{\circ} \mathrm{N}-50^{\circ} \mathrm{N}$. Middle, $20^{\circ} \mathrm{S}-20^{\circ} \mathrm{N}$. Bottom, $30^{\circ} \mathrm{S}-50^{\circ} \mathrm{S}$. The vertical black dot-dash line at 1997 indicates the turnaround date. The solid black lines indicate the fitted trend to the all instrument average before and after 1997. Trend values are given in $\%$ decade $^{-1}$ and uncertainties are 2 standard deviations. Please note that the $20^{\circ} \mathrm{S}-20^{\circ} \mathrm{N}$ contains a QBO contribution, while the extra tropical bins have the QBO removed.

result of the "change in linear trend method". Newchurch et al. (2003) only apply a linear trend from 1993 until 1997, thus they only consider the anomalies during this time, while the change in linear trend method looks for a specific temporal path through the whole data set. The difference being in this case that the method used here produces a less steep fit to the data in comparison to the Newchurch et al. (2003) method. Trend values after 1997 all show consistent declines in $\mathrm{HCl}:-5.2 \% \pm 2.2 \%$ decade $^{-1}$ in the southern midlatitudes and $-5.1 \% \pm 2.1 \%$ decade $^{-1}$ in the northern hemispheric mid-latitudes. These values are all statistically significant from a zero trend at $2 \sigma$. It is also seen that the sudden increase in values after 2001 (most apparent in $30^{\circ} \mathrm{S}-50^{\circ} \mathrm{S}$ ) reported in Fig. 1 is still present, implying that according to this analysis it is neither a related feature of seasonal or QBO behaviour. This feature may be related to possible anomalous atmospheric dynamics in the Southern Hemisphere, such as the Antarctic ozone hole split in 2002 (Manney et al., 2005; Charlton et al., 2005) and/or changes in tropical upwelling due to enhanced wave driving in 2000-2001 (Dhomse et al., 2008). The tropics bin from $20^{\circ} \mathrm{S}-20^{\circ} \mathrm{N}$ shows a more negative trend of $5.8 \%$ decade $^{-1}$ since 1997 compared to the mid-latitudes. However, we have not removed the QBO contribution from HALOE or ACE time series, suggesting the calculated trend could be different if the QBO contribution is removed.

\section{$4.2 \mathrm{ClO}$}

A summary of the scaled SMR and MLS measurements is presented in Fig. 8. The upper panel illustrates AM and PM scaled monthly means for both SMR and MLS. It can be seen that there is an excellent agreement between the average SMR AM and PM scaled values. There is however about a 0.1-0.2 ppbv difference between MLS AM and PM scaled values. The MLS AM measurements are made typically when the LST is between 01:00 $\mathrm{h}$ and 03:00 $\mathrm{h}$, a time when $\mathrm{ClO}$ concentrations are close to zero ppbv below $40 \mathrm{~km}$. As a result, small systematic errors of the measurements may be amplified by the diurnal correction factors, yielding in this case unrealistically high scaled measurement values. The end result is a larger layer average. Due to this problem, we have decided to ignore the MLS night time measurements, thus we only consider MLS PM observations for the construction of the all instrument average (note, that the offset is applied to the MLS PM anomalies so that they fit relative to the SMR PM anomalies). The bottom panel of Fig. 8 shows the SMR scaled monthly means (combination of AM and PM) as well as the MLS PM scaled monthly means. There is a good agreement between the two scaled data sets, where each individual time series shows evidence for structural components due to natural variability, including the seasonal and QBO cycles. Differences between MLS and SMR are typically no larger than $\sim 0.03 \mathrm{ppbv}$ and there is also clear evidence that the LST trend in the SMR measurements is removed.

Examination of the $\mathrm{ClO}$ all instrument average based on the anomalies, with the seasonal and QBO cycles removed, is shown in Fig. 9. The top panel shows the SMR contribution to the all instrument average, while the bottom panel considers MLS. The trend calculated for the 2001-2008 period from both the combined data sets is $-7.1 \% \pm 7.8 \%$ decade $^{-1}$, implying that it is not statistically significant from a zero trend at $2 \sigma$.

\section{Discussion of $\mathrm{HCl}$ and $\mathrm{ClO}$ results}

The $\mathrm{ClO}$ trend value obtained here is considerably less negative than the analysis performed by Solomon et al. (2006), who used ground based millimetre wave measurements at Mauna Kea in Hawaii, USA, to observe $\mathrm{ClO}$ concentrations. They found a significant linear decline of $\mathrm{ClO}$ of $-15 \% \pm 2 \% /$ decade from $1995-2005$ for altitudes between 35 and $39 \mathrm{~km}$, although they estimate that about $30 \%$ of this decline can be attributed to methane $\left(\mathrm{CH}_{4}\right)$ increments (a sink of $\mathrm{Cl}$ ) in this altitude range, which have been measured by HALOE. A recent update of this analysis, where the time series was extended to 2007, shows a $\mathrm{ClO}$ trend of $-9 \% \pm 2 \%$ decade $^{-1}$ (WMO, 2011). Our values are more consistent with the analysis by O'Doherty et al. (2004), who estimate that tropospheric $\mathrm{Cl}_{\mathrm{y}}$ is decreasing between 6 and 

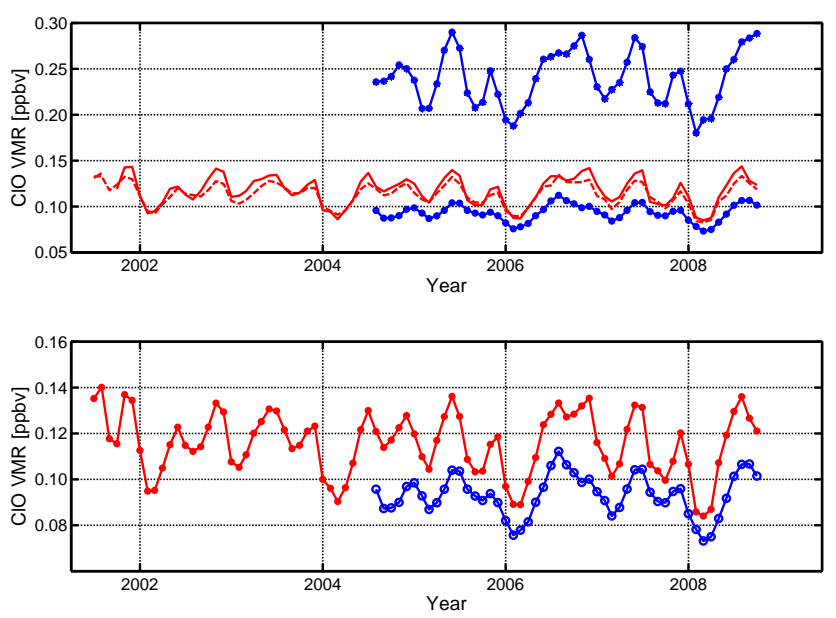

Fig. 8. Scaled SMR and MLS ClO observations as a function of time for $35-45 \mathrm{~km}$ and $20^{\circ} \mathrm{S}-20^{\circ} \mathrm{N}$. Top, AM and PM scaled monthly averages; MLS AM blue star, MLS PM blue dot, SMR dawn red solid line, SMR dusk red dash line. Bottom, SMR (red) scaled combined AM and PM profiles, and MLS scaled (blue) day profiles.
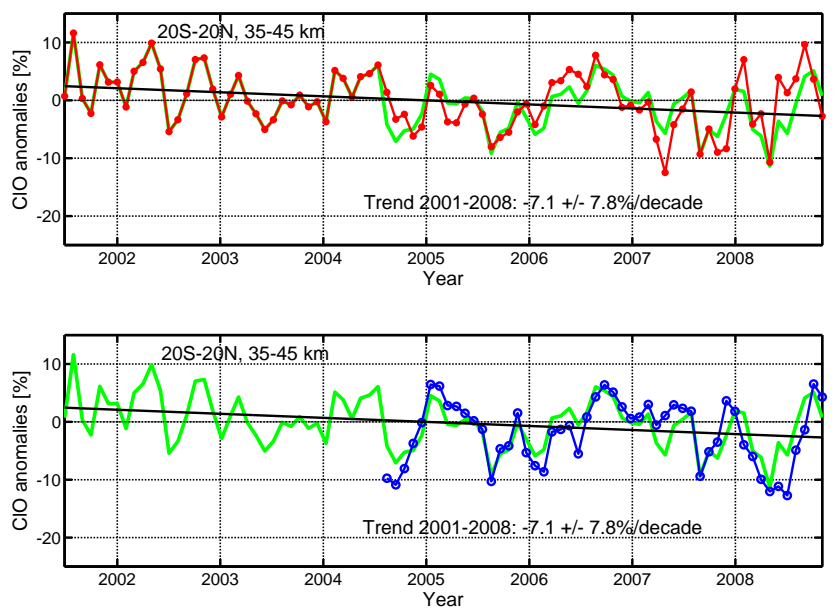

Fig. 9. $\mathrm{ClO}$ anomalies for SMR (red) and MLS (blue) for $20^{\circ} \mathrm{S}-$ $20^{\circ} \mathrm{N}$ and $35-45 \mathrm{~km}$. Also shown under-laid is the all instrument average (green). The solid black line shows the linear trend fitted to the all instrument average. Trend value given in $\%$ decade $^{-1}$ and uncertainties are at 2 standard deviations.

$8 \%$ decade $^{-1}$. We have also compared our $\mathrm{ClO}$ trend value with results from the Canadian Middle Atmospheric Model (CMAM) (Beagley et al., 1997; de Grandpré et al., 2000) for the same time period, altitude layer, and latitudes bins used here (see the SPARC CCMVal "REF2" scenario described in Eyring et al. (2005) for further details). The CMAM model estimates a trend of $\sim-7 \%$ decade $^{-1}$ since January 2001 until the end of 2008, which is of similar magnitude with our calculated trend value.
Table 1. HALOE trend and uncertainty $(2 \sigma)$ estimates before and after 1997.

\begin{tabular}{lrr}
\hline Bin & Trend before 1997 & Trend after 1997 \\
\hline $30^{\circ} \mathrm{S}$ to $25^{\circ} \mathrm{S}$ & $28 \pm 1.4 \%$ decade $^{-1}$ & $-5.2 \pm 1.9 \%$ decade $^{-1}$ \\
$25^{\circ} \mathrm{S}$ to $20^{\circ} \mathrm{S}$ & $30 \pm 1.4 \%$ decade $^{-1}$ & $-6.0 \pm 2.0 \%$ decade $^{-1}$ \\
$20^{\circ} \mathrm{S}$ to $15^{\circ} \mathrm{S}$ & $26.7 \pm 1.6 \%$ decade $^{-1}$ & $-5.6 \pm 1.8 \%$ decade $^{-1}$ \\
$15^{\circ} \mathrm{S}$ to $10^{\circ} \mathrm{S}$ & $23.8 \pm 1.5 \%$ decade $^{-1}$ & $-5.6 \pm 1.5 \%$ decade $^{-1}$ \\
$10^{\circ} \mathrm{S}$ to $5^{\circ} \mathrm{S}$ & $21.4 \pm 1.6 \%$ decade $^{-1}$ & $-5.3 \pm 2.0 \%$ decade $^{-1}$ \\
$5^{\circ} \mathrm{S}$ to $0^{\circ}$ & $24.3 \pm 2.1 \%$ decade $^{-1}$ & $-5.7 \pm 2.7 \%$ decade $^{-1}$ \\
$0^{\circ}$ to $5^{\circ} \mathrm{N}$ & $16.9 \pm 1.8 \%$ decade $^{-1}$ & $-4.2 \pm 2.2 \%$ decade $^{-1}$ \\
$5^{\circ} \mathrm{N}$ to $10^{\circ} \mathrm{N}$ & $23.8 \pm 1.5 \%$ decade $^{-1}$ & $-4.1 \pm 1.9 \%$ decade $^{-1}$ \\
$10^{\circ} \mathrm{N}$ to $15^{\circ} \mathrm{N}$ & $21.7 \pm 1.5 \%$ decade $^{-1}$ & $-4.6 \pm 1.9 \%$ decade $^{-1}$ \\
$15^{\circ} \mathrm{N}$ to $20^{\circ} \mathrm{N}$ & $26.1 \pm 1.5 \%$ decade $^{-1}$ & $-5.5 \pm 1.9 \%$ decade $^{-1}$ \\
$20^{\circ} \mathrm{N}$ to $25^{\circ} \mathrm{N}$ & $25.7 \pm 1.5 \%$ decade $^{-1}$ & $-5.3 \pm 1.9 \%$ decade $^{-1}$ \\
$25^{\circ} \mathrm{N}$ to $30^{\circ} \mathrm{N}$ & $23.1 \pm 1.4 \%$ decade $^{-1}$ & $-4.5 \pm 1.7 \%$ decade $^{-1}$ \\
$10^{\circ} \mathrm{S}$ to $10^{\circ} \mathrm{N}$ & $22.5 \pm 1.7 \%$ decade $^{-1}$ & $-5.3 \pm 2.1 \%$ decade $^{-1}$ \\
$15^{\circ} \mathrm{S}$ to $15^{\circ} \mathrm{N}$ & $23.2 \pm 1.5 \%$ decade $^{-1}$ & $-5.4 \pm 1.9 \%$ decade $^{-1}$ \\
$20^{\circ} \mathrm{S}$ to $20^{\circ} \mathrm{N}$ & $24.7 \pm 1.4 \%$ decade $^{-1}$ & $-5.7 \pm 1.8 \%$ decade $^{-1}$ \\
$30^{\circ} \mathrm{S}$ to $30^{\circ} \mathrm{N}$ & $26.6 \pm 1.4 \%$ decade $^{-1}$ & $-5.7 \pm 1.4 \%$ decade $^{-1}$ \\
\hline
\end{tabular}

Newchurch et al. (2003) examined HALOE observations from $30^{\circ} \mathrm{S}-30^{\circ} \mathrm{N}$, but as HALOE had a sparse coverage due to the temporal progression of the scans as the satellite orbited from pole to pole, it means the total global coverage varied strongly from year-to-year. This implies that a bin covering a $60^{\circ}$ span over the tropical zone is perhaps too large and there will be strong influences from different chemical and dynamical regimes. In order to test how the HALOE $\mathrm{HCl}$ behaves in the tropics, we have examined HALOE residuals in $5^{\circ}$ latitude bands spanning $30^{\circ} \mathrm{S}-30^{\circ} \mathrm{N}$. The HALOE residuals examined have only the seasonal component removed. As there is a sparse amount of data in each five degree bin, estimating a QBO component could be challenging, hence the QBO component is retained in the residuals. Using the analogy of Eq. (2), we apply the Reinsel et al. (2002) fitting technique to the HALOE residuals from January 1993 to November 2005 with a turnaround of January 1997. Table 1 shows the estimated trends before and after the turnaround date for the five degree latitude bins and four extra larger bins for a fuller comparison: $10^{\circ} \mathrm{S}-10^{\circ} \mathrm{N}, 15^{\circ} \mathrm{S}-15^{\circ} \mathrm{N}, 20^{\circ} \mathrm{S}-$ $20^{\circ} \mathrm{N}$, and $30^{\circ} \mathrm{S}-30^{\circ} \mathrm{N}$.

From Table 1, it can be seen that the range of $\mathrm{HCl}$ trend values from each five degree latitude bin after 1997 are in the range of $-4 \%$ to $-6 \%$ decade $^{-1}$. It is also apparent that $\mathrm{HCl}$ increases at a higher rate prior to 1997 as one moves away from the equator. This is possibly due to a combination of stronger wave dynamics, which rapidly transport the tropical air towards the mid-latitudes. Moreover, the production of $\mathrm{HCl}$ is greater outside the tropics as CFCs are more rapidly broken down here due to longer residence times at the higher stratospheric altitudes. Consequently, $\mathrm{HCl}$ is destroyed faster as one moves away from the pole, resulting 
from a peak and decline in CFC concentrations after 1997. Examination of the trends for the four larger bins $\left(10^{\circ} \mathrm{S}-\right.$ $10^{\circ} \mathrm{N}, 15^{\circ} \mathrm{S}-15^{\circ} \mathrm{N}, 20^{\circ} \mathrm{S}-20^{\circ} \mathrm{N}$, and $30^{\circ} \mathrm{S}-30^{\circ} \mathrm{N}$ ) shows that the differences in trend magnitude between each bin is relatively small, indicating that the use of larger bins is acceptable, although caution is needed. We chose to use $20^{\circ} \mathrm{S}-20^{\circ} \mathrm{N}$ for representing the tropics in Fig. 7 so as to stay consistent with the $\mathrm{ClO}$ analysis. It should be noted that the trends for $20^{\circ} \mathrm{S}-20^{\circ} \mathrm{N}$ in Fig. 7 are slightly different to those in Table 1. This is simply because the ACE-FTS data has now been added to the all instrument average, which alters the time series properties when the Reinsel fit is made. The all instrument average for the tropics (and the tropical trend estimates from Table 1) are not dissimilar from the mid-latitude all instrument average trends shown in Fig. 7, although the QBO contributions are removed from the midlatitude calculations and not for the tropics. It suggests that since 2005 until present, $\mathrm{HCl}$ has continued to decrease at a similar rate. Solomon et al. (2006) also investigated HALOE $\mathrm{HCl}$ between 35 and $39 \mathrm{~km}$ for $10^{\circ} \mathrm{N}-30^{\circ} \mathrm{N}$, where they applied a fit to the HALOE data from 1997-2005, producing a $\mathrm{HCl}$ linear trend of $-5 \% \pm 1.2 \%$ decade $^{-1}$, which is similar to the all instrument average values found in this study as well as the HALOE values from Table 1. Simulated CMAM monthly averaged $\mathrm{HCl}$ values show that from 1997 to 2008 $\mathrm{HCl}$ decreases by $-3.1 \%$ decade $^{-1}$, for $35-45 \mathrm{~km}$ at northern mid-latitudes and $-4.1 \%$ decade $^{-1}$ at Southern Hemisphere mid-latitudes, values which are slightly less than our estimated trend values. The difference in trend values can be attributed to differences in the choice of peak loading times of $\mathrm{HCl}$ assumed here and to that found in the CMAM model, where CMAM HCl peaks typically around 1999 and not 1997. Recent trend analyses concerning the upper stratosphere $(\sim 55 \mathrm{~km})$ have been performed, using various satellite and ground-based data. Aura-MLS and ACE-FTS trend values show a decline in $\mathrm{HCl}$ to be $-6 \% \pm 1 \%$ decade $^{-1}$ and $-9 \% \pm 2 \%$ decade $^{-1}$ respectively, since 2004 . Moreover, ground-based FTIR total column measurements of $\mathrm{HCl}$ at Jungfraujoch and Kiruna show similar trends from 19962009: $-9 \% \pm 1 \%$ decade $^{-1}$ and $-8 \% \pm 2 \%$ decade $^{-1}$ respectively (WMO, 2011). These reported trends are larger in magnitude compared to here. However these differences can be possibly explained due to contrasts in $\mathrm{HCl}$ abundances with respect to altitude. $\mathrm{HCl}$ is estimated to account for $>95 \%$ of the total chlorine above $50 \mathrm{~km}$ compared to $\sim 80$ $90 \%$ between 35 and $45 \mathrm{~km}$ (WMO, 2006). Moreover, there are different chemical and dynamical processes controlling the evolution of $\mathrm{HCl}$ throughout the stratosphere, hence we do not necessarily expect to see similar trend magnitudes.

Linear trend model uncertainties are mainly determined by three factors: the time series length, the autocorrelation of the residuals, and variance of the residuals factors (Weatherhead et al., 1998; Reinsel et al., 2002). In this analysis, we find the $\mathrm{ClO}$ all instrument average anomalies to have an autocorrelation of 0.51 , which is moderate (the degree of correlation increases towards 1 or -1 ), while the standard deviation is $4.4 \%$. The $\mathrm{ClO}$ anomalies of course still have variations due to the solar cycle included, which will account for some of the variance and autocorrelation in the modeled values. The variation of tropical $\mathrm{ClO}$ due to changes in solar intensity is estimated to be as much as $2 \%$ between 35 and $40 \mathrm{~km}$, but it is almost negligible between 40 and $45 \mathrm{~km}$ according to model simulations (Egorova et al., 2005). The total length of the time series is also quite short, which means it is hard to differentiate between long and short term variations. Inevitably, the regression parameter errors will be reduced when the time series is extended (assuming that the other two influencing parameters remain constant). A longer time series will also mean that a reasonable solar cycle estimate can be made to help further reduce some of the uncertainty.

Ultimately, the apparent decline in chlorine compounds should mean an anti-correlation with ozone. Recent ozone trends calculated for 1997 onwards in this altitude region have shown signs of a small recovery (but not significantly different from a zero trend), although the magnitudes found are typically smaller than those of the chlorine species reported here. Jones et al. (2009) reported that ozone is increasing at $\sim 1.7 \%\left( \pm \sim 2.0 \%\right.$ decade $\left.^{-1}\right)$ at mid-latitudes based on linear trends from 1997-2008, while Steinbrecht et al. (2006) suggest a 1997-2005 trend for Hawaii to be increasing by $1.9 \% \pm 1.9 \%$ decade $^{-1}$. Both of these examples show trend magnitudes to be less than the trend values estimated here using $\mathrm{HCl}$ and $\mathrm{ClO}$. This implies that ozone's recovery is also dependent on other atmospheric parameters and not just entirely on chlorine chemistry. For example, ozone is influenced by cycles involving, $\mathrm{ClO}, \mathrm{BrO}, \mathrm{NO}_{\mathrm{x}}$, and $\mathrm{HO}_{\mathrm{x}}$ and thus depends on changes of the source gases of these families (for example, $\mathrm{H}_{2} \mathrm{O}$ and $\mathrm{CH}_{4}$ for the $\mathrm{HO}_{\mathrm{x}}$ family) (WMO, 2006).

\section{Summary}

We have analysed the long-term evolution of stratospheric $\mathrm{HCl}$, using combined HALOE and ACE-FTS $\mathrm{HCl}$ measurements from 1993-2008. Furthermore, we have estimated a trend in stratospheric $\mathrm{ClO}$, using measurements from the Aura-MLS and Odin/SMR over a shorter time period, 20012008. The analyses shown here utilise monthly averaged data in the $35-45 \mathrm{~km}$ altitude region for two mid-latitude bands $\left(30^{\circ} \mathrm{S}-50^{\circ} \mathrm{S}\right.$ and $\left.30^{\circ} \mathrm{N}-50^{\circ} \mathrm{N}\right)$ for $\mathrm{HCl}$, while $\mathrm{ClO}$ and $\mathrm{HCl}$ measurements are examined for the tropics $\left(20^{\circ} \mathrm{S}-20^{\circ} \mathrm{N}\right)$.

We find that the SMR ascending and descending node LSTs are monotonically increasing in time since its launch. This has resulted in $\mathrm{ClO}$ measurements being significantly influenced by lower SZAs during morning scans and higher SZAs during evening scans. To remove the LST trend in the data, a 1-D atmospheric box model is used to determine scale factors, which are applied to the measurements so that they will represent a value when the SZA equals $90^{\circ}$ during 
sunrise. The same method is applied to the MLS data so that a comparison can be made. However, the computed scale factors for MLS night profiles are overestimated due to the very low night time $\mathrm{ClO}$ abundances below $40 \mathrm{~km}$. As a result, only the MLS PM scaled values are considered in the trend analysis. SMR scaled values show consistency between AM and PM profiles, thus both sets of scaled values are used.

Anomalies of the monthly averages are calculated by removing the seasonal and QBO cycles. However, due to the sparse ACE-FTS $\mathrm{HCl}$ data around the tropics, we only remove the seasonal cycle in the tropics bin. The anomalies are then concatenated in each respective bin to produce all instrument averages, which are used for the trend analysis. $\mathrm{HCl}$ trend estimates after 1997 are $-5.1 \pm 2.1 \%$ decade $^{-1}$ (northern mid-latitudes), whilst $-5.2 \pm 2.2 \%$ decade $^{-1}$ (southern mid-latitudes) in the upper stratosphere, and $-5.8 \pm 2.2 \%$ decade $^{-1}$ in the tropics. The modeling uncertainties indicate that the estimated trends are significantly different from a zero trend at $2 \sigma$. ClO trend estimates show slightly larger trend magnitudes since 2001, although not statistically significant at $2 \sigma$ $\left(7.1 \pm 7.8 \%\right.$ decade $\left.^{-1}\right)$. It is expected that in the future uncertainties of the $\mathrm{ClO}$ analysis can be reduced by employing a longer time series. It will also allow for the possibility to estimate the contribution of the solar cycle. This shows the importance of time series length. The fact that SMR has out lived its 2 year expected life time is a bonus as it has provided one of the longest $\mathrm{ClO}$ data sets so far, hence it is important that the observations continue to be made until the satellite finally ceases to naturally operate. This is also certainly applicable for ACE-FTS, MLS, and other recent satellite instruments.

The results found here are in agreement with and extend on previous findings (for example, Considine et al., 1997, 1999; Anderson et al., 2000; Newchurch et al., 2003; Froidevaux et al., 2006; Solomon et al., 2006; WMO, 2006). Although the $\mathrm{ClO}$ trend is not statistically significant, it does imply a reduction over the past 7 years, while the $\mathrm{HCl}$ trend shows a clear statistically significant downward trend. These results illustrate that the Montreal protocol and the subsequent amendments are having an impact on the total chlorine concentration in the stratosphere and ultimately the recovery of ozone.

Acknowledgements. Odin is a Swedish-led satellite project funded jointly by the Swedish National Space Board (SNSB), the European Space Agency (ESA), the Canadian Space Agency (CSA), the National Technology Agency of Finland (Tekes) and the Centre National d'Etudes Spatiales (CNES) in France. The Atmospheric Chemistry Experiment (ACE), also known as SCISAT-1 is a Canadian led mission mainly supported by the Canadian Space Agency (CSA). Work at the Jet Propulsion Laboratory, California Institute of Technology was done under contract with the National Aeronautics and Space Administration. Thanks also to Erik Zakrisson and Marcus Jansson for their assistance and input concerning the atmospheric box model. We would also like to thank the
EU-SCOUT-O3 project and those involved for their contribution to funding this work. Thanks also to Andreas Jonsson at the University of Toronto, Canada, for his help with the CMAM data.

Edited by: W. T. Sturges

\section{References}

Anderson, J., Russell III, J. M., Solomon, S., and Deaver, L. E.: Halogen Occultation Experiment confirmation of stratospheric chlorine decreases in accordance with the Montreal Protocol, J. Geophys. Res., 105, 4483-4490, 2000.

Baldwin, M. P., Gray, L. J., Dunkerton, T. J., Hamilton, K., Haynes, P. H., Randel, W. J., Holton, J. R., Alexander, M. J., Hirota, I., Horinouchi, T., Jones, D. B. A., Kinnersley, J. S., Marquardt, C., Sato, K., and Takahashi, M.: The Quasi-Biennial Oscillation, Rev. Geophys., 39, 179-229, 2001.

Beagley, S. R., de Grandpré, J., Koshyk, J. N., McFarlane, N. J., and Shephard, T. G.: Radiative-dynamical climatological of he first-generation Canadian Middle Atmospheric Model, Atmos.Ocean, 35, 293-331, 1997.

Bernath, P. F., McElroy, C. T., Abrams, M. C., Boone, C. D., Butler, M., Camy-Peyret, C., Carleer, M., Clerbaux, C., Coheur, P. F., Colin, R., DeCola, P., De Maziére, M., Drummond, J. R., Dufour, D., Evans, W. F. J., Fast, H., Fussen, D., Gilbert, K., Jennings, D. E., Llewellyn, E. J., Lowe, R. P., Mahieu, E., Mc-Connell, J. C., McHugh, M., McLeod, S. D., Michaud, R., Midwinter, C., Nassar, R., Nichitiu, F., Nowlan, C., Rinsland, C. P., Rochon, Y. J., Rowlands, N., Semeniuk, K., Simon, P., Skelton, R., Sloan, J. J., Soucy, M. A., Strong, K., Tremblay, P., Turnbull, D., Walker, K. A., Walkty, I., Wardle, D. A., Wehrle, V., Zander, R., and Zou, J.: Atmospheric Chemistry Experiment (ACE): Mission overview, Geophys. Res. Lett., 32, L15S01, doi:10.1029/2005GL022386, 2005.

Boone, C. D., Nassar, R., Walker, K. A., Rochon, Y., McLeod, S. D., Rinsland, C. P., and Bernath, P. F.: Retrievals for the Atmospheric Chemistry Experiment Fourier transform spectrometer, Appl. Optics, 44(33), 7218-7231, 2005.

Bracher, A., Sinnhuber, M., Rozanov, A., and Burrows, J. P.: Using a photochemical model for the validation of $\mathrm{NO}_{2}$ satellite measurements at different solar zenith angles, Atmos. Chem. Phys., 5, 393-408, doi:10.5194/acp-5-393-2005, 2005.

Brohede, S., McLinden, C. A., Berthet, G., Haley, C. S., Murtagh, D., and Sioris, C. E.: A stratospheric $\mathrm{NO}_{2}$ climatology from Odin/OSIRIS Limb-scatter measurements, Can. J. Phys, 85, 1253-1274, 2007a.

Brohede, S., Haley, C. S., McLinden, C. A., Sioris, C. E., Murtagh, D. P., Petelina, S. V. Llewellyn, E. J., Bazureau, A., Goutail, F., Randall, C. E., Lumpe, J. D., Taha, G., Thomasson, L. W., and Gordley, L. L.: Validation of Odin/OSIRIS stratospheric NO2 profiles, J. Geophys. Res., 112, D07310, doi:10.1029/2006JD007586, 2007b.

Charlton, A. J., O'Neill, A., Lahoz, W. A., and Berrisford, P.: The Splitting of the Stratospheric Polar Vortex in the Southern Hemisphere, September 2002: Dynamical Evolution, J. Atmos. Sci., 62(3), 590-602, 2005.

Considine, G. D., Deaver, L., Remsberg, E. E., and Russell III, J. M.: HALOE Observations of a Slowdown in the Rate of Increase 
of HF in the Lower Mesosphere, Geophys. Res. Lett., 24(24), 3217-3220, 1997.

Considine, G. D., Deaver, L., Remsberg, E. E., and Russell III, J. M.: Analysis of Near- Global Trends and Variability in HALOE $\mathrm{HF}$ and $\mathrm{HCl}$ Data in the Middle Atmosphere, J. Geophys. Res., 104, 24297-24308, 1999.

de Grandpré, J., Beagley, S. R., Fomichev, V. I., Griffoen, E., McConnell, J. C., Medvedev, A. S., and Shepherd, T. G.: Results from the Canadian Middle Atmosphere Model, J. Geophys. Res., 105, 26475-26491, 2000.

Dhomse, S., Weber, M., and Burrows, J.: The relationship between tropospheric wave forcing and tropical lower stratospheric water vapor, Atmos. Chem. Phys., 8, 471-480, doi:10.5194/acp-8-4712008, 2008.

Egorova, T., Rozanov, E., Zubov, V., Schmutz, W., and Peter, Th.: Influence of solar 11-year variability on chemical composition of the stratosphere and mesosphere simulated with a chemistry-climate model, Adv. Space Res., 451-457, doi:10.1016/j.asr.2005.01.048, 2005.

Eyring, V., Kinnison, D. E., and Shepherd, T. G.: Overview of planned coupled chemistry-climate simulations to support upcoming ozone and climate assessments, SPARC Newsletter, 25, 11-17, 2005.

Frisk, U., Hagstrom, M., Ala-Laurinaho, J., Andersson, S., Berges, J. C., Chabaud, J. P., Dahlgren, M., Emrich, A., Floren, H. G., Florin, G., Fredrixon, M., Gaier, T., Haas, R., Hirvonen, T., Hjalmarsson, A., Jakobsson, B., Jukkala, P., Kildal, P. S., Kollberg, E., Lassing, J., Lecacheux, A., Lehikoinen, P., Lehto, A., Mallat, J., Marty, C., Michet, D., Narbonne, J., Nexon, M., Olberg, M., Olofsson, A. O. H., Olofsson, G., Origne, A., Petersson, M., Piironen, P., Pons, R., Pouliquen, D., Ristorcelli, I., Rosolen, C., Rouaix, G., Raisanen, A. V., Serra, G., Sjoberg, F., Stenmark, L., Torchinsky, S., Tuovinen, J., Ullberg, C., Vinterhav, E., Wadefalk, N., Zirath, H., Zimmermann, P., and Zimmermann, R.: The Odin Satellite: I. Radiometer Design and Test, Astron. Astrophys., 402, 27-34, 2003.

Froidevaux, L., Livesey, N. J., Read, W. G., Salawitch, R. J., Waters, J. W., Drouin, B. J., MacKenzie, L .A., Pumphrey, H. C., Bernath, P., Boone, C., Nassar, R., Montzka, S., Elkins, J., Cunnold, D., and Waugh, D.: Temporal decrease in upper atmospheric chlorine, Geophys. Res. Lett., 33, L23812, doi:10.1029/2006GL027600, 2006.

Froidevaux, L., Jiang, Y. B., Lambert, A., Livesey, N. J., Read, W. G., Waters, J. W., Fuller, R. A., Marcy, T. P., Popp, P. J., Gao, R. S., Fahey, D. W., Jucks, K. W., Stachnik, R. A., Toon, G. C., Christensen, L .E., Webster, C. R., Bernath, P .F., Boone, C. D., Walker, K .A., Pumphrey, H. C., Harwood, R. S., Manney, G. L., Schwartz, M. J., Daffer, W. H., Drouin, B. J., Cofield, R. E., Cuddy, D. T., Jarnot, R. F., Knosp, B. W., Perun, V. S., Snyder, W. V., Stek, P. C., Thurstans, R. P. and Wagner, P. A.: Validation of Aura Microwave Limb Sounder $\mathrm{HCl}$ measurements, J. Geophys. Res., 113, D15S25, doi:10.1029/2007JD009025, 2008.

Jonsson, A.: Modelling: the middle stratosphere and its sensitivity to climate change, Dept. of Met. Stockholm University, PHD thesis, 2006.

Jones, A., Urban, J., Murtagh, D. P., Eriksson, P., Brohede, S., Haley, C., Degenstein, D., Bourassa, A., von Savigny, C., Sonkaew, T., Rozanov, A., Bovensmann, H., and Burrows, J.: Evolution of stratospheric ozone and water vapour time series studied with satellite measurements, Atmos. Chem. Phys., 9, 6055-6075, doi:10.5194/acp-9-6055-2009, 2009.

Jucks, K. W., Johnson, D. G., Chance, K. V., Traub, W. A., Salawitch, R. J., and Stachnik, R. A.: Ozone production and loss rate measurements in the middle stratosphere, J. Geophys. Res., 101(D22), 28785-28792, 1996.

Manney, G. L., Sabutis, J. L., Allen, D. R., Lahoz, W. A., Scaife, A. A., Randall, C. E., Pawson, S., Naujokat, B., and Swinbank, R.: Simulations of Dynamics and transport during the September 2002 Antarctic Major Warming, J. Atmos. Sci., 62, 3, 690-707, 2005.

Mahieu, E., Duchatelet, P., Demoulin, P., Walker, K. A., Dupuy, E., Froidevaux, L., Randall, C., Catoire, V., Strong, K., Boone, C. D., Bernath, P. F., Blavier, J.-F., Blumenstock, T., Coffey, M., De Maziére, M., Griffith, D., Hannigan, J., Hase, F., Jones, N., Jucks, K. W., Kagawa, A., Kasai, Y., Mebarki, Y., Mikuteit, S., Nassar, R., Notholt, J., Rinsland, C. P., Robert, C., Schrems, O., Senten, C., Smale, D., Taylor, J., Tétard, C., Toon, G. C., Warneke, T., Wood, S. W., Zander, R., and Servais, C.: Validation of ACE-FTS v2.2 measurements of $\mathrm{HCl}$, $\mathrm{HF}, \mathrm{CCl}_{3} \mathrm{~F}$ and $\mathrm{CCl}_{2} \mathrm{~F}_{2}$ using space-, balloon- and ground-based instrument observations, Atmos. Chem. Phys., 8, 6199-6221, doi:10.5194/acp-8-6199-2008, 2008.

Molina, M. J. and Rowland, F. S.: Stratospheric sink for chlorofluoro-methanes: Chlorine atom catalysed destruction of ozone, Nature, 249, 810-812, 1974.

Murtagh, D., Frisk, U., Merino, F., Ridal, M., Jonsson, A., Stegman, J., Witt, G., Eriksson, P., Jimenez, C., Mégie, G., Noëë, J. de La ., Ricaud, P., Baron, P., Pardo, J.-R. , Hauchecorne, A. , Llewellyn, E. J., Degenstein, D. A., Gattinger, R. L., Lloyd, N. D., Evans, W. F. J., McDade, I. C., Haley, C., Sioris, C., Savigny, C. von, Solheim, B. H., McConnell, J. C., Strong, K., Richardson, E. H., Leppelmeier, G. W., Kyrölä, E., Auvinen, H., and Oikarinen, L.: An overview of the Odin atmospheric mission, Can. J. Phys., 80, 309-319, 2002.

Newchurch, M. J., Yang, E. S., Cunnold, D. M., Reinsel, G. C., Zawodny, J. M., and Russel III, J. M.: Evidence for slowdown in stratospheric ozone loss: First stage of ozone recovery, J. Geophys. Res., 108(D16), doi:10.1029/2003JD003471, 2003.

Newman, P. A., Daniel, J. S., Waugh, D. W., and Nash, E. R.: A new formulation of equivalent effective stratospheric chlorine (EESC), Atmos. Chem. Phys., 7, 4537-4552, doi:10.5194/acp7-4537-2007, 2007.

O’Doherty, S., Cunnold, D. M., Manning, A., Miller, B. R., Wang, R. H. J., Krummel, P. B., Fraser, P. J., Simmonds, P. G., McCulloch, A., Weiss, R. F., Salameh, P., Porter, L. W., Prinn, R. G., Huang, J., Sturrock, G., Ryall, D., Derwent, R. G., and Montzka, S. A.: Rapid growth of hydrofluorocarbon 134a and hydrochlorofluorocarbons 141b, 142b, and 22 from Advanced Global Atmospheric Gases Experiment (AGAGE) observations at Cape Grim, Tasmania, and Mace Head, Ireland, J. Geophys. Res., 109, D06310, doi:10.1029/2003JD004277, 2004.

Rinsland, C. P., Mathieu, E., Zander, R., Jones, N. B., Chipperfield, M. P., Goldman, A., Anderson, J., Russell, J. M., Demoulin, P., Notholt, J., Toon, G. C., Blavier, J. F., Sen, B., Sussmann, R., Wood, S. W., Meier, A., Griffith, D. W. T., Chiou, L. S., Murcray, F. J., Stephen, T. M., Hase, F., Mikuteit, S., Schulz, A., and Blumenstock, T.: Long-term trends of inorganic chlorine from ground-based infrared solar spectra: Past increases 
and evidence for stabilization J. Geophys. Res., 108(D8), 4252, doi:10.1029/2002JD003001, 2003.

Reinsel, G. C., Weatherhead, E. C., Tiao, G. C., Miller, A. J., Nagatani, R. M., Wuebbles, D. J., and Flynn, L. E.: On detection of turnaround and recovery in trend for ozone, J. Geophys. Res., 107(D10), 4078, doi:10.1029/2001JD000500, 2002.

Russell III, J. M., Gordley, L. L., Park, J. H., Drayson, S. R., Hesketh, D. H., Cicerone, R. J., Tuck, A. F., Frederick, J. E., Harries, J. E., and Crutzen, P.: The Halogen Occultation Experiment, J. Geophys. Res., 98(D6), 10777-10797, 1993.

Russell III, J. M., Deaver, L. E., Luo, M. Z., Park, J. H., Gordley, L. L., Tuck, A. F., Toon, G. C., Gunson, M. R., Traub, W. A., Johnson, D. G., Jucks, K. W., Murray, D. G., Zander, R., Nolt, I. G., and Webster, C. R.: Validation of hydrogen chloride measurements made by the Halogen Occultation Experiment from the UARS platform, J. Geophys. Res., 101, 10151-10162, 1996.

Santee, M. L., Lambert, A., Read, W. G., Livesey, N. J., Manney, G. L., Cofield, R. E., Cuddy, D. T., Daffer, W. H., Drouin, B. J., Froidevaux, L., Fuller, R. A., Jarnot, R. F., Knosp, B. W., Perun, V. S., Snyder, W. V., Stek, P. C., Thurstans, R. P., Wagner, P. A., Waters, J. W., Connor, B., Urban, J., Murtagh, D., Ricaud, P., Barrett, D., Kleinboehl, A., Kuttippurath, J., Kullmann, H., von Hobe, M., Toon, G. C., and Stachnik, R. A.: Validation of the Aura Microwave Limb Sounder ClO Measurements, J. Geophys. Res., 113, D15S22, doi:10.1029/2007JD008762, 2008.

Schoeberl, M. R., Douglass, A. R., Polansky, B., Boone, C., Walker, K. A., and Bernath, P.: Estimation of stratospheric age spectrum from chemical tracers, J. Geophys. Res., 110, D21303, doi:10.1029/2005JD006125, 2005.

Solomon, P., Barrett, J., Mooney, T., Connor, B., Parrish, A., and Siskind, D. E.: Rise and decline of active chlorine in the stratosphere, Geophys. Res. Lett., 33, L18807, doi:10.1029/2006GL027029, 2006.

Steinbrecht, W., Claude, H., and Winkler, P.: Enhanced stratospheric ozone: Sign of recovery or solar cycle?, J. Geophys. Res., 109, D2308, doi:10.1029/2003JD004284, 2004.

Steinbrecht, W., Claude, H., Schönenborn, F., McDermid, I. S., Leblanc, T., Godin, S., Song, T., Swart, D. P. J., Meijer, Y. J., Bodeker, G. E., Connor, B. J., Kämpfer, N., Hocke, K., Calisesi, Y., Schneider, N., de la No, J., Parrish, A. D., Boyd, I. S., Brühl, C., Steil, B., Giorgetta, M. A., Manzini, E., Thomason, L.W., Zawodny, J. M., McCormick, M. P., Russell III, J. M., Bhartia, P. K., Stolarski, R. S., and Hollandsworth-Frith, S .M.: Long-term evolution of upper stratospheric ozone at selected stations of the Network for the Detection of Stratospheric Change (NDSC), J. Geophys. Res., 111, D10308, doi:10.1029/2005JD006454, 2006.
Stiller, G. P., von Clarmann, T., Höpfner, M., Glatthor, N., Grabowski, U., Kellmann, S., Kleinert, A., Linden, A., Milz, M., Reddmann, T., Steck, T., Fischer, H., Funke, B., LópezPuertas, M., and Engel, A.: Global distribution of mean age of stratospheric air from MIPAS SF 6 measurements, Atmos. Chem. Phys., 8, 677-695, doi:10.5194/acp-8-677-2008, 2008.

Urban, J., Lautié, N., Le Flochmoën, E., Jiménez, C., Eriksson, P., de La Noë, J., Dupuy, E., Ekström, M., El Amraoui, L., Frisk, U., Murtagh, D., Olberg, M., and Ricaud, P.: Odin/SMR limb observations of stratospheric trace gases: Level 2 processing of $\mathrm{ClO}, \mathrm{N}_{2} \mathrm{O}, \mathrm{HNO}_{3}$, and $\mathrm{O}_{3}$, J. Geophys. Res., 110(D14), D14307, doi:10.1029/2004JD005741, 2005.

Urban, J., Murtagh, D., Lautié, N., Barret, B., de La Noë, J., Frisk, U., Jones, A., Le Flochmoën, E., Olberg, M., Piccolo, C., Ricaud P., and Rösevall, J.: Odin/SMR limb observations of trace gases in the polar lower stratosphere during 2004-2005, Proc. ESA First Atmospheric Science Conference, 8-12 May 2006, Frascati, Italy/editor Lacoste, H., ESA-SP-628 Noordwijk: European Space Agency. ISBN/ISSN: ISBN-92-9092-939-1, ISSN-1609042X, 2006.

Waters, J. W., Froidevaux, L., Harwood, R. S., Jarnot, R. F., Pickett, H. M., Read, W. G., Siegel, P. H., Cofield, R. E., Filipiak, M. J., Flower, D. A., Holden, J. R., Lau, G. K., Livesey, N. J., Manney, G. L., Pumphrey, H. C., Santee, M. L., Wu, D. L., Cuddy, D. T., Lay, R. R., Loo, M. S., Perun, V. S., Schwartz, M. J., Stek, P. C., Thurstans, R. P., Boyles, M. A., Chandra, K. M., Chavez, M. C., Chen, G.-S., Chudasama, B. V., Dodge, R., Fuller, R. A., Girard, M. A., Jiang, J. H., Jiang, Y., Knosp, B. W., Labelle, R. C., Lam, J. C., Lee, A. K., Miller, D., Oswald, J. E., Patel, N. C., Pukala, D. M., Quintero, O., Scaff, D. M., Vansnyder, W., Tope, M. C., Wagner, P. A., and Walch, M. J.: The Earth Observing System Microwave Limb Sounder (EOS MLS) on the Aura satellite, IEEE T. Geosci. Remote Sens., 55, 1075-1092, 2006.

Waugh, D. W., Considine, D. B., and Fleming, E. L.: Is Upper Stratospheric Chlorine Decreasing as Expected?, Geophys. Res. Lett., 28(7), 1187-1190, 2001.

Weatherhead, E. C., Reinsel, G. C., Tiao, G. C., Meng, X-Li, Choi, D., Cheang, W. K., Keller, T., DeLuisi, J., Weubbles, D. J., Kerr, J. B., Miller, A. J., Oltmans, S. J., and Frederick, J. E.: Factors affecting the detection of trends: Statistical considerations and applications to environmental data, J.Geophys. Res., 103(D14), 17149-17116, 1998.

World Meteorological Organization (WMO): Scientific Assessment of Ozone Depletion, 2006, Geneva, 2006.

World Meteorological Organization (WMO): Scientific Assessment of Ozone Depletion, 2010, Geneva, 2011. 